DOI https://doi.org/10.30525/978-9934-26-113-8-34

\title{
POLYSACCHARIDES RESEARCH OF THYMUS PULEGIOIDES L.
}

\author{
Steshenko Ya. M. \\ $P h D$ - student, \\ Teaching Assistant at the Department of Pharmacy Management \\ and Economics and Pharmaceutical Technology \\ Zaporizhzhia State Medical University
}

\author{
Aksonova I. I. \\ $P h D$, \\ Teaching Assistant at the Department of Pharmacognosy, \\ Pharmacology and Botany \\ Zaporizhzhia State Medical University
}

Maliuhina O. O.

PhD, Senior lecturer at the Department of Pharmacy Management and Economics and Pharmaceutical Technology

Zaporizhzhia State Medical University

Fukleva L. A.

$P h D$,

Senior lecturer at the Department of Pharmacy Management and Economics and Pharmaceutical Technology

Zaporizhzhia State Medical University

Mazulin O. V.

Dr.hab.,

Professor at the Department of Clinical Pharmacy, Pharmacotherapy,

Pharmacognosy and Pharmaceutical Chemistry

Zaporizhzhia State Medical University

Zaporizhzhia, Ukraine

Nowaday, the specie of the genus Thymus $L$. is one of the most populare specie in the Europe. Lamiaceae is a very polymorphic species in different parts of Ukraine. For example, in the scientific literature indicated that some species (T.vulgaris, T.serpyllum) have anti-inflammatory and antioxidant properties and use in phytotherapy. Today pharmacognosy studies the 
chemical composition of medicinal plants and the products of their primary processing. In our experimantal part we used raw materials (herba) were harvested in Ukraine. Many modern medicines include several coppounds, which makes them more effective. The traditional methods of analysis for the determination of polysaccharides in medicinal plant materials pharmaceutical substances of plant and herbal preparations can't provide. Phytopreparations based on them are used as expectorants and anti-inflammatory agents. Thymus pulegioides L. is found in both wild and cultivated. having female individuals. Polysaccharides are one of the most important of the family of biopolymers. Polysaccharides have a wide bioactivities. Polysaccharide preparations are used as anti-inflammatory, immunostimulating agents. Herbal infusion and liquid extract of thyme have expectorant, antibacterial, antispasmodic and analgesic effect; calming effect on the central nervous system,stimulate the secretion of gastric juice. Thyme is part of the drugs Pertusin, Anitos. Pectic substances have a high therapeutic effect. The aim of the work was to study the monosaccharide composition of WSPS and PS in this species as a phytochemical research in pharmacy.There is no information in the literature on the study of polysaccharide complexes of grass of promising species of the genus Thymus L. From the essential oil of thyme is obtained thymol - a strong antiseptic, which is used for disinfection of the oral cavity, treatment of fungal skin lesions, in dental practice. Pharmacological activity of different groups of polysaccharides has common features. The compounds have reparative, antiinflammatory and antimicrobial properties. All polysaccharides are adsorbents. Polysaccharides affect various physiological and biochemical processes in plants, as well as in organisms of humans and animals. Exzogenous polysaccharides at introduction into the body can reduce inflammation, accelerate reparative processes.[1-5]. Polysaccharides are a widespread group of BAS in plant raw materials, which has an enveloping, emollient, antiinflammatory, wound-healing effect, are used in diseases of the nasopharynx, bronchitis,intestinal diseases.In general, polysaccharides affect the state of the pancreas. It is established that polysaccharides herbal complexes are actively used in modern herbal medicine. The phytochemical study of PSC was carried out by paper chromatography, gravimetry and spectrophotometry.

In the experimental part, it was found that this species is promising for polysaccharide determination. It's consist WSPS ( $2,18 \pm 0.22)$ and PS $(1,24 \pm 0.22)$. In the course of research, we identified the composition of polysaccharides in raw materials (herba). It is established that phytostudy of little-studied plant species is perspective for the development of plant-based drugs 


\section{References:}

1. Pavel M. Essential oils of Thymus pulegioides and Thymus glabrescens from Romania: chemical composition and antimicrobial activity / M. Pavel, M. Ristic, T. Stevic // J. Serb. Chemic. Soc. - 2010. - Vol. 75, № 1. - P. 27-34.

2. Arsenic, cadmium and lead in medicinal herbs and their fractionation/S. Arpadjan, G. Ģelik, S. Taşkesen, Ş. Güçer et al. Food and chemical toxicology.2008. Vol. 46, N 8. P. 2871-2875.

3. Rajkapoor B., Burkan Z. E., Kumar R. S. Oxidants and human diseases : role of antioxidant medicinal plants - a review. Pharmacology. 2010. Vol. 85, N 1. P. 1117-1131.

4. Komaki A. Study of the Effect of Extract of Thymus Vulgaris on Anxiety in Male Rats / A. Komaki, F. Hoseini, S. Shahidi, N. Baharlouei // Journal of Traditional and Complementary Medicine. - 2016. - 6(3). P. 257-261.

5. Фуклева Л. А. Изучение состава и возможность использования чабреца обыкновенного и крымского в фармацевтической практике / Л. А. Фуклева, Л. А. Пучкан. - Научные ведомости. Серия медицина, фармация. - 2013. -№ 18 (161), вып. 21. - С. 207-210. 